\title{
Leather Industry in Bangladesh: A Systematic Literature Review
}

\author{
Wahiduzzaman Khan ${ }^{1 *}$, Md. Ekram Hossin ${ }^{2}$, Md. Jamshed Akbor \\ ${ }^{1}$ Assistant Professor, School of Business, Asian University of Bangladesh, BANGLADESH \\ ${ }^{2}$ Self Researcher, Dhaka, BANGLADESH \\ ${ }^{3}$ Managing Director, NICL Properties \& Developers Ltd, BANGLADESH \\ *E-mail for correspondence: wzk roence@yahoo.co.uk \\ Cell Phone: +88 01939993399
}

\begin{abstract}
There has been a moderate number of research works, published and unpublished, relating to the broader field of leather industry in Bangladesh. Research on and for the leather industry has undoubtedly grown-up in contemporary years. The existing socio-economic condition of Bangladesh provides an encouraging prospect for leather Industry. It attracted many economists, environmentalists and technical persons to do research works regarding various aspects of this sector. This study makes a humble attempt to present a brief review of the existing relevant literature on the leather industry of Bangladesh.
\end{abstract}

Keywords: Leather Industry, Bangladesh, Leather Export

\section{INTRODUCTION}

The leather and its related downstream industries can claim to be the world's largest industrial sector based upon a by-product. In the case of leather, the raw material is a by-product of the meat industry. Hides and skins and their downstream products are vital earners of foreign exchange and they compare very well with the other agricultural commodities and, in fact, with any internationally traded commodities. The country's tanneries and leather, leather goods and footwear makers are putting on war paint to battle for more orders in the international markets (Sarker, 2000). The hides, skins and leather industry is one of the key agricultural subsectors with a high potential towards commodity development that addresses pertinent issues of socio economic importance and positively impacts on rural development, creation of wealth and employment.

The contribution of the sub sector towards achieving economic growth through an expansion of the export market for both semi-processed and finished leather goods is immense and the only way to such success is through embracing the value addition initiatives. This is the direction that the Ministry has adopted and strongly pursues to meet the industry's demand (Mohapatra, 2002). The EPB's data revealed that leather goods exports, during the period between July 2012 and January 2014, were to the tune of $\$ 149.46$ million, which is 8.46 per cent lower than the target of $\$ 163.28$ million. An analysis of the EPB data showed that the country's leather product export earnings were forging ahead due to growing international demand for Bangladeshi leather products, mainly for quality and cheaper prices (Export Promotion Bureau, 2014).
But in terms of export earnings leather products lag far behind finished leather. According to the statistical data of EPB, the country earned $\$ 31.40$ million through exports of leather products during the July 2012-January 2014 period; the earning was 62.11 per more than the targeted figure of $\$ 19.37$ million. During the last seven months of the current fiscal, exporters of leather products registered 145.70 per cent earnings growth over that in the corresponding period of the previous year. Further expansion of the labor-intensive leather industry will create more employment opportunities compared to other export sectors. In most developing countries tanning operations is a family business, carried out in small to medium scale semi-mechanized units, very frequently grouped tightly in clusters which used to be outside residential areas (Ahmad, 2005). Tanners in such units have no formal education and have little or no understanding of the complexities of the leather processing, their skills acquired from their elders with hardly any perception of environmental protection Low waste technologies, generally speaking, require better skilled personnel and closer technical control than conventional processing (Dhanarajan, 2006). Thus, lack of properly trained staff at different levels remains one of the crucial constraints.

\section{Methodology}

This study reviewed the literature on leather industry in Bangladesh for the database of ScienceDirect, Emerald Fulltext, Springer, abcGATE, Infor-Sci, IGI Global, Taylor \&Francis, EBSCOhost, and IngentaJournals. The search engines Google Scholar and Scopus were also used to ensure coverage of publications in other databases. The 
following criteria were used to search these sources and select the papers:

- The keywords leather, social, economic, and Bangladesh were used to search the titles and abstracts of the papers.

- Conference papers, master's theses, doctoral dissertations, textbooks and unpublished working papers were excluded because academics and practitioners generally use journals to acquire information and disseminate new findings.

- Different types of journal publications (peerreviewed, published, in press), with available English full text versions, were all considered. It is noteworthy that the decision to include non-peer reviewed papers was important as it recognized the value of editorial and invited commentaries in shaping the research within a discipline.

\section{FINDINGS}

The first detailed baseline survey of leather industrial sector of Bangladesh was organized in 1979-80 by the committee on Development of Leather Export level headed by the government of Bangladesh. This extended survey made a package of recommendations together with prohibition of wet-blue export, return of duty on imported leather processing chemicals for export of crust and finished leather, cash subsidy on export of crust, finished leather and leather products at the rate of $9 \%$, $12 \%$ and $15 \%$ respectively on FOB value, air freight subsidy at the rate of $15 \%$ of FOB value, bank finances for capital investment and working capital, etc. to encourage export of crust, finished and leather products. They also advocated for progress of required infrastructure facilities including water supply, road and drainage system, power and gas, building up a National Leather Institute for R\&D and formation of leather Board to help the development of leather sector. This report was followed by a number of studies in the middle of 1980s.

In 1981 The World Bank carried out a study for the leather manufacturing industries as a review of the Second FiveYear Plan. As part of the ESCAP attempt to identify the leather manufacturing industries as prime conveyor for development of industries in Bangladesh, on behalf of BSCIC (Bangladesh Small and Cottage Industries Corporation). Chowdhury (1982) made a study on leather and leather products industries of Bangladesh in 1981-82 and indicated a number of development action plans and specific role of the BSCIC. Winters (1983) surveyed the tanning industry as a sub sector in 1983 on behalf of UNIDO and achieved that installed capacity for wet-blue was 171 million square feet against total accessibility of 100 million square feet of hides and skins.

In mid 1980s, TIP (Trade and Industrial Policy) Reform Program of Bangladesh Planning Commission assisted two important studies. These report showed acceptable economic and financial rates of return in the transformation of wet blue into crust and finished leather. Haq and Islam (1988) in a study in 1988 recorded that the social rates of return is higher than the financial rates in the processing of finished leather for export. Our government has provided various incentives packages to footwear and leather goods export to ensue the policy suggested by TIP.

Huq and Islam (1990) made one of the pioneering efforts (Choice of Technology: A Case study of leather manufacturing in Bangladesh) in the form of a pilot inquiry. They made an in-depth study of the leather manufacturing industry focusing on technology transfer in Bangladesh in 1988. The study attempted to identify alternative techniques by types and sources and then evaluated in the light of the existing input costs and revenue earned (cost effectiveness) in the context of development objectives of the dominion. An equal improvement in technology selection involving the use of least cost techniques including machinery and equipment from local sources will greatly help to reduce unit cost of production and at the same time it will help the development of the local capital goods sector.

Huq and Ahmed (1990) created only four week's brief survey on "Bangladesh Leather Sector-strategy for Further Development" from mid- December 1989 to midJanuary 1990 for Harvard Institute for International Development's Employment and Small Enterprise Policy (ESEP) project, Bangladesh Planning Commission, Government of Bangladesh. They identified some major constraints in expansion and development of leather manufacturing industry- such as working capital, technical know-how, management, skilled operators, administrative bottlenecks, customs formalities, frequent changes in policy decisions, etc. and suggested a number of policy changes including BMRE. They also suggested to move finished leather to footwear and leather products for export, withdrawal of incentives on crust export to assure development of finished leather, grant cash subsidy for export of leather products, use of export potentials of small and cottage level footwear and leather goods sub-sector, strengthening of training facilities at Leather College, setup Common Finishing Facility Center, development of R\&D facilities, etc.

International Trade Center (ITC) implemented an Export Development Project during 1991-1994 for the Government of Bangladesh (GOB) to help export development of non-traditional items including leather and leather products. Attempts were made to find joint venture or technical collaboration partners for leather sector industries at market places and market familiarization visits to potential selected markets but the achievement was not up to satisfaction. A few foreign firms showed interest in marketing and technical collaboration but none entered final contract. Bangladesh is so weak in the case of market promotion for all traditional and nontraditional products especially for leather and leather products. 
In 1995 Research department of Bangladesh Bank has undertaken a detailed study on the basis of survey to examine the export potentialities of leather \& leather goods sector. The Team conducted the survey and prepared a report on the basis of in-depth analysis of the available data and the situation prevailing in different areas of leather and leather manufacturing businesses of the country. The report ended with some suggestions for development of the sector. Karim (1996) had an attempt to update present knowledge of leather industry, undertook a study which was published by the World Bank Resident Mission, Dhaka, as "Industrialization Strategy study of Bangladesh: Export prospects For Leather and Leather products". The objective of the study was to assess prospects and possibilities for developing forward linkage with leather goods manufacturing. The specific investigation encompassed grounds such as the size and structure, production facilities and production issues, procurement of raw materials, laborer skill, marketing of leather, management and environmental issues.

Islam and Faiz (1997) made a study on "The Leather and Leather Product Industry and The Informal Credit Market in Bangladesh". They determined the urban informal monetary market in Bangladesh with specific reference to its significance in financing the Leather and Leather products manufacturing industry and business. In this study they investigated the size and trend of the activity in its different stages such as hide and skin curing, tanning, manufacturing leather and leather products and their marketing channel. The study attempted to locate the geographic concentration of the activity and to discuss the contemporary production methods and rates of return from the activity and to identify several constraints and ordered to credit rating, unhealthy credit giving system in the institutional sources, etc. They emphasized the extent of informal financing, the sources of credit and the altogether usefulness of the informal financial sector in promotion activity for leather manufacturing sector.

Ahmed (2002) in the study titled "Inventory of Leather Sector of Bangladesh: Problems and Prospects" made an intensive survey. For Bangladesh Finished Leather, Leather goods and Footwear Exporters' Association (BFLLFEA) with financial assistance of the Matching Grant Facility Management Units, a component of Export Development Project of GOB and the World Bank. This study was undertaken for a thorough study of leather sector industries of the country covering all aspects of manufacture to assess the present status of raw material supply, capacity and production of leather and leather products, to identify problems of production and export and determine needs for the development of industries to make optimum use of the potentials of local raw stock.

Besides these, there are some papers relating to various factor of leather sector. These papers contained some general discussions, suggestions and conclusions and were not directly involved with applied studies on this sector. In this respect, work of Manzur (1994) and Mahtab (1998) received wide attention. Manzur (1994) in his paper "Leather Industry-The present and Future" highlighted the prospect of leather industry of Bangladesh and its development over the years. He pointed out the advantageous position of our leather industry from various points of view.

A number of studies have addressed economic, social, and community development issues in rural areas. However, few have combined these constructs into a theoretical framework that can be used to project the impact of a leather-finishing facility on a small town. The major purposes of this study were to project the social and economic impact from establishing a new leather finishing facility in a rural community and to development an application model through which community business development decisions could be made. In a survey, Huq and Hossain (1996) has reported that manufacturing industries in and around Dhaka city provide about 2, 70,000 jobs. Zahur (2006) found that leather industries have enough scope for both vertical and horizontal expansion in terms of economic return and social benefits. The global competition has been the major driver that forced the leather industry to upgrade its technological base. A tanner has limited opportunities to isolate any high labor cost and shift it to a low-cost area. European and North American tanners and manufactures have introduced computerization and robotics to reduce the labor input, rationalize selection and production control, and improve effluent quality and discharge volumes. In Bangladesh, the manufacturing of wet blue, the chrome tanned semi-processed leather, was featured in 1965. Earning foreign exchange apart, such trade expansion would mean generation of substantial employment, skill building, and entrepreneurship development and widely spread socio-economic benefits. For Bangladesh, therefore, the growth of the leather industry is a direct contribution to rural advancement and socioeconomic development.

The leather is a unique commodity that links grassroots villages with high societies and traditional practices with emerging technologies. For many developing countries, leather and leather manufacturers constitute an indispensable and dependable source for export trade and foreign exchange earnings. For Bangladesh, leather is a high priority industrial sector and footwear exports, an extreme focus area. Bangladesh has, just few decades since Independence, made significant gains from the leather trade, progressing from the status of an exporter of $90 \%$ plus raw hides and skins to that of an exporter and predominantly leather product manufacturer. The leather tanning and finishing, silk and synthetic textile, printing and publishing show no significance change in total factor productivity over time. However, the results concerning technical efficiency, in turn, suggest that three remains a wider scope for the improvement of technical efficiency of firms in most of the industries. 
In Bangladesh a very insignificant amount of money is used for environmental research work due to scarcity of financial support. That is why money supply is unsatisfactory in this field. But in the developed countries there are special research works about the pollution caused by tannery industries. SEHD (Society for Environment and Human Development 1998) has studied the environmental pollution in Hazaribagh aiming at developing realistic recommendations for mitigating pollution. This report has been prepared with findings from studies, observations and laboratory tests. CBI of the Neatherlands organized a study on pollution issues of tanneries in Hazaribagh zone on behalf of Asian Development Bank in 1995. They suggested establishing a common plant for treatment of wastewater of tanneries before discharge to surface water and estimating an expected cost for consideration of ADB and the Government of Bangladesh.

Rahman (1984) studied to estimate the polluting effect of tannery waste and to improve appropriate processing method for the harmless disposal of this waste. Rahman (1988) made an effort to determine the degree of pollution at Hazaribagh by reason of discharge of tannery waste and to make a parallel study of onsite treatment versus shifting of the tanneries at Nayarhat, Dhaka.

Alam (2001) aimed an investigation on pollution control and discovered that in traditional way, tannery production causes wastage of water, chemicals, lime and electricity, which had a direct influence on the production cost, quality of leather and harmful for health. UNIDO's regional program had taken a comprehensive view of the environment problems caused by the tanning industry of Bangladesh. The primary strategy of this program is to estimate the pollution load in the discharged effluents and introduce cleaner technologies in production, which effectively reduce the pollution pressure and amount of effluent. UNIDO was hoped for to setup one Central Effluent Treatment Plant at Hazaribagh for the overall environment management. However, still it is on processing.

Stephens (1978) visited 40 tanneries in the country to evaluate their infrastructure, production capabilities and market expertise. He also visited the technological institutions. He surveyed the market for hides and skins in Dhaka for several days. He suggested improvement in the tactics of flaying and curing of hides and skins and grading. Raha (1993) analyzed the stock position of hides and skins in Bangladesh and showed that cattle and goat population raised by .49 and .196 million heads per year, respectively and the increase rate of cattle and buffalo hides supply was about $4.5 \%$, as long as the supply of goat and sheep skins were $9.3 \%$ and $2.3 \%$, respectively. The present situation of livestock production indicated that there is an inadequate scope to further increase the supply of hides and skins in the country. However, scopes exist for betterment of quality of hides and skins.
Nooruddin and Dey (1993) determined the degree of economic losses by reason of numerous leather defects based on primary and secondary data in Bangladesh. The primary data covered grading and recording of the size of 13,156 crust leathers (e.g. leathers made from cattle hides 6,087; buffalo hides 2,027; goat skins 2,522; sheep skins 2,520). A plentiful proportion of leathers were detected to be downgraded and dropped by the defects in leathers made from cattle hides (98.9\%), buffalo hides $(100.0 \%)$, goats' skins $(92.0 \%)$, and sheep skins (94.0\%). An annual (1990-91) economic loss of US\$ 220.95 million (Taka 818.0 crores approximately, 55.2\%) was estimated to be allied with various leather defects. Major ingredients of these losses (in million US \$) were $194.45(88.01 \%)$ for leathers made from cattle hides, 1.88 $(0.85 \%)$ for buffalo hides, $24.09(10.90)$ for goatskins and $0.52(0.21 \%)$ for sheepskins. Consequently, the control of leather defects is essential for the purpose of value addition and improvement in the national economy.

BARC (2001) was conducted for reviewing the government development plans and policies, management system, production, processing and constraints to hides and skins in Bangladesh. Moreover, to support the review work, 100 market intermediaries from 5 divisions, 40 tanneries, 10 leather and leather goods industries and 200 households who sacrificed animals during Eid-ul- Azaha (the largest religious festival of the Muslim) 2001, were randomly selected from 5 divisions of the country. The study review the government development plans and policies on procurement, processing, preservation and trading of hides and skins in the country and identified the constraints responsible for hindering the overall production and trading of hides and skins.

Several factors must be considered when determining approaches for social and economic development within communities. Mills (1995) stated that, the goal of community economic development efforts and professional economic developers should be the improvement of the economic well-being of the community and enhancement of the overall quality of life for all members of the community. Bergstrom, Cordell, Watson, and Ashley (1990) suggested that new industrial development does not always provide large increases in jobs and salaries for local workers. Ranney (1997) recommended the need to focus on ordinary people in relation to economic development. He posited that tax burdens on lower and middle-income community residents tend to increase while underemployment often continues to rise.

Bruner and Parachini provided a clear mandate that economic development must be closely interrelated with the social, economic, and political dimensions of a community so that economic growth will be sustained. Within this framework, one perceives the need to identify the community characteristics of any given rural environment or small town so as to assess its strengths and weaknesses. 
The main findings of the study, conducted by Krishna and Sahota (1991), on productivity growth and time invariant technical efficiency are that about one half of the industries covered under the study are suffering from stagnation as far as productivity is concerned; some of the industries (cotton textile, grain milling and cigarettes) are characterized by acceleration in the growth in total factor productivity.

Azom et al. (2012) conducted a study on tanneries of Hazaribag located in Dhaka to assess the present scenario. They unearth the environmental impacts of these industries through Environment Impact Assessment (EIA). This study found that there is a significant impact on employment as they are earning rather than remaining unemployed. However, it creates several health problems on workers of this tannery. Muhammad and Haque (2012) conducted a survey on tannery industries of Hazaribug area to investigate the effect of industrial pollution on the physical and mental health of the tannery workers as well as the related residential area's people of Hagaribag in Dhaka city. The results of this study suggested that physical health of related residential area's people is better than that of tannery workers. They also found that tannery creates the job opportunity.

Rouf et al (2013) conducted a study at leather industries of Hazaribagh, Dhaka to evaluate the tannery effluent quality. The samples of effluent were taken from seven leather industries and three places around the area of leather industries. The odour of the samples was more or less pungent. The color of the samples was blackish blue, violet, brown, black etc. Khan (2015) found that Leather and leather manufacturers constitute an indispensable and dependable source for export trade and foreign exchange earnings. For Bangladesh, leather is a high priority industrial sector and footwear exports, an extreme focus area. The Table shows the summary of findings of researchers on leather industry in Bangladesh.

Table: Summary of Findings

\begin{tabular}{|c|c|c|c|}
\hline Author & Year & Title & Findings \\
\hline $\begin{array}{l}\text { Committee on } \\
\text { development of } \\
\text { Leather Export }\end{array}$ & $1979-80$ & $\begin{array}{l}\text { "Report of the Committee on } \\
\text { Development of Leather } \\
\text { Export" }\end{array}$ & $\begin{array}{l}\text { The committee gave some recommendation based on the study. } \\
\text { They are: } \\
\text { 1. Wet-blue export should be prohibited } \\
\text { 2. Cash subsidy on export on crust } \\
\text { 3. Bank financing for capital investment and for working } \\
\text { capital } \\
\text { 4. Infrastructural development } t \text { ( such as water , road \& } \\
\text { transportation etc.) }\end{array}$ \\
\hline $\begin{array}{l}\text { TIP reform } \\
\text { program of } \\
\text { Bangladesh } \\
\text { Industrial Planning } \\
\text { Commission } \\
\end{array}$ & 1980 & $\begin{array}{l}\text { "Program of Bangladesh } \\
\text { Industrial Planning } \\
\text { Commission" }\end{array}$ & $\begin{array}{l}\text { Show the economic and financial rate of return in the } \\
\text { transformation of west-blue to crust and finished leather. }\end{array}$ \\
\hline Chowdhury & 1982 & $\begin{array}{l}\text { "Leather tanning and leather } \\
\text { products in Bangladesh" }\end{array}$ & $\begin{array}{l}\text { Try to indicate a number of development action plans and } \\
\text { specific the role of BSCIC. }\end{array}$ \\
\hline $\begin{array}{l}\text { Winters (on } \\
\text { behalf of UNIDO) }\end{array}$ & 1983 & $\begin{array}{l}\text { "Leather Industry } \\
\text { Development and Export: } \\
\text { Bangladesh" }\end{array}$ & The capacity is much more than the accessibility on that time. \\
\hline Haq and Islam & 1988 & $\begin{array}{l}\text { "Financial return in the } \\
\text { finished leather export in } \\
\text { Bangladesh" }\end{array}$ & $\begin{array}{l}\text { Social rate of return than financial rate of return in the } \\
\text { processing of finished leather for export. }\end{array}$ \\
\hline Huq and Islam & 1990 & $\begin{array}{l}\text { "Leather Industry in } \\
\text { Bangladesh: Challenges and } \\
\text { Techniques" }\end{array}$ & $\begin{array}{l}\text { Alternative and new techniques are more cost effective than } \\
\text { existing techniques. }\end{array}$ \\
\hline $\begin{array}{l}\text { Huq and } \\
\text { Ahmed }\end{array}$ & 1990 & $\begin{array}{l}\text { "Bangladesh Leather Sector- } \\
\text { strategy for Further } \\
\text { Development" }\end{array}$ & $\begin{array}{l}\text { There are some major constrains in expansion and development of } \\
\text { leather manufacturing industry such as working capital, technical } \\
\text { know-how, management, skilled operator, administrative bottlenecks, } \\
\text { custom formalities, frequent change in policy decisions etc. }\end{array}$ \\
\hline World Bank & 1993 & $\begin{array}{l}\text { "Industrialization Strategy } \\
\text { Study of Bangladesh Export } \\
\text { Prospects of leather and } \\
\text { leather products" }\end{array}$ & $\begin{array}{l}\text { To identify the leather manufacturing industry as a prime } \\
\text { conveyor of development of industry in Bangladesh. }\end{array}$ \\
\hline $\begin{array}{l}\text { International } \\
\text { Trade Center }\end{array}$ & $1991-94$ & $\begin{array}{lrr}\text { "Market Promotion } & \text { for } \\
\text { Leather Goods } & \text { in } \\
\text { Developing Countries" } & \\
\end{array}$ & $\begin{array}{l}\text { Bangladesh is so weak in case of market promotion especially } \\
\text { for leather goods. }\end{array}$ \\
\hline $\begin{array}{l}\text { Research } \\
\text { Department of } \\
\text { BB }\end{array}$ & 1995 & $\begin{array}{l}\text { "Leather and Leather Goods } \\
\text { in Bangladesh: Export } \\
\text { Potentiality and Challenges" }\end{array}$ & $\begin{array}{l}\text { The export possibility of leather and leather goods sector is } \\
\text { potential but need some development. }\end{array}$ \\
\hline
\end{tabular}




\begin{tabular}{|c|c|c|c|}
\hline Karim & 1996 & $\begin{array}{l}\text { "Export Prospect for Leather } \\
\text { and Leather Product" }\end{array}$ & $\begin{array}{l}\text { Some prospects and possibilities for developing forward } \\
\text { linkage with leather goods manufacturing. }\end{array}$ \\
\hline Islam and Faiz & 1997 & $\begin{array}{l}\text { "The Leather and Leather } \\
\text { Product Industry and The } \\
\text { Informal Credit Market in } \\
\text { Bangladesh" }\end{array}$ & $\begin{array}{l}\text { The size and trend of the activity in its different stages such as } \\
\text { hide and skin curing, tanning, manufacturing leather and } \\
\text { leather products and their marketing channel. The relationship } \\
\text { between geographical area and unhealthy credit system. }\end{array}$ \\
\hline $\begin{array}{l}\text { SEHD } \text { (Society } \\
\text { for Environment } \\
\text { and Human } \\
\text { Development) }\end{array}$ & 1988 & $\begin{array}{l}\text { "Leather Industry- } \\
\text { Environmental Pollution and } \\
\text { Mitigation Measures" }\end{array}$ & They gave realistic recommendations for mitigating pollution. \\
\hline $\begin{array}{l}\text { CBI of the } \\
\text { Neatherlands }\end{array}$ & 1995 & $\begin{array}{l}\text { "Treatment of Wastewater of } \\
\text { Tanneries in Bangladesh" }\end{array}$ & $\begin{array}{l}\text { Establishing a common plant for treatment of wastewater of } \\
\text { tanneries before discharge to surface water was suggested and } \\
\text { cost was estimated. }\end{array}$ \\
\hline $\begin{array}{l}\text { Huq and } \\
\text { Hossain }\end{array}$ & 1996 & $\begin{array}{l}\text { "Critical environmental } \\
\text { issues relating to tanning } \\
\text { industries in Bangladesh" }\end{array}$ & $\begin{array}{l}\text { Although leather manufacturing have some environmental } \\
\text { problem, it provided about } 270000 \text { jobs }\end{array}$ \\
\hline Rahman & 1984 & $\begin{array}{l}\text { "A Study on Policy, } \\
\text { Management and Constraints } \\
\text { to Processing of Hides and } \\
\text { Skins in Bangladesh" }\end{array}$ & $\begin{array}{l}\text { Estimated the polluting effect of tannery waste and improved } \\
\text { appropriate processing method for the harmless disposal of this } \\
\text { waste. }\end{array}$ \\
\hline Rahman & 2001 & $\begin{array}{l}\text { "Environmental Effect of Leather } \\
\text { Industry in Bangladesh" }\end{array}$ & $\begin{array}{l}\text { Degree of pollution at Hazaribagh by reason of discharge of } \\
\text { tannery waste. }\end{array}$ \\
\hline Alam & 2001 & $\begin{array}{l}\text { "UNIDO Regional Program for } \\
\text { Pollution Control for an } \\
\text { Environmentally } \quad \text { Sustainable } \\
\text { Leather Industry in Bangladesh" }\end{array}$ & $\begin{array}{l}\text { How pollution can be controlled with the traditional way of } \\
\text { production. }\end{array}$ \\
\hline Raha & 1993 & $\begin{array}{l}\text { "RecentTrends in Livestock } \\
\text { Population and products in } \\
\text { Bangladesh" }\end{array}$ & $\begin{array}{l}\text { Cattle and goat population raised by } .49 \text { and } .196 \text { million heads } \\
\text { per year, respectively and the increase rate of cattle and buffalo } \\
\text { hides supply was about } 4.5 \% \text {, as long as the supply of goat and } \\
\text { sheep skins were } 9.3 \% \text { and } 2.3 \% \text {, respectively. }\end{array}$ \\
\hline $\begin{array}{l}\text { Nooruddin and } \\
\text { Dey }\end{array}$ & 1993 & $\begin{array}{l}\text { "The Economic Impact of } \\
\text { Leather Industry in } \\
\text { Bangladesh" }\end{array}$ & $\begin{array}{l}\text { The degree of economic losses by reason of numerous leather } \\
\text { defects based on primary and secondary data in Bangladesh. } \\
\text { The annual economic loss of US } \$ 220.95 \text { million (Taka } 818.0 \\
\text { crores approximately. }\end{array}$ \\
\hline BRAC & 2001 & $\begin{array}{l}\text { "Hide and Skin Production } \\
\text { in Bangladesh" }\end{array}$ & $\begin{array}{l}\text { Review the government development plans and policies on } \\
\text { procurement, processing, preservation and trading of hides and } \\
\text { skins in the country and identified the constraints responsible for } \\
\text { hindering the overall production and trading of hides and skins. }\end{array}$ \\
\hline Ahmed & 2002 & $\begin{array}{l}\text { "Prospect of Leather Product } \\
\text { Export from Bangladesh and } \\
\text { Its Requirements" }\end{array}$ & $\begin{array}{l}\text { Assessed the present status of raw material supply, capacity } \\
\text { and production of leather and leather products, identified } \\
\text { problems of production and export and determine needs for the } \\
\text { development of industries to make optimum use of the } \\
\text { potentials of local raw stock. }\end{array}$ \\
\hline Ahmed & 2005 & $\begin{array}{l}\text { "Value-added Transformation } \\
\text { of Leather Industry in } \\
\text { Bangladesh-Present Position } \\
\text { and Future Prospects" }\end{array}$ & $\begin{array}{l}\text { In most developing countries, tanning operations are a family } \\
\text { business and carried out in small and medium scale. The } \\
\text { business normally situated outside residential area. }\end{array}$ \\
\hline Dhanaranjan & 2006 & $\begin{array}{l}\text { "Leather Industry in } \\
\text { Bangladesh: } \quad \text { Perspective } \\
\text { from Business" }\end{array}$ & $\begin{array}{l}\text { Tanners in family business have no formal education and a } \\
\text { little or sometimes no learning about the complexities of leather } \\
\text { processing or environmental protection and wastage of leather }\end{array}$ \\
\hline Zahur & 2006 & $\begin{array}{l}\text { "Solid waste management of } \\
\text { Dhaka city: public private } \\
\text { community partnership" }\end{array}$ & $\begin{array}{l}\text { Leather industries have enough scope for both vertical and } \\
\text { horizontal expansion in terms of economic return and social } \\
\text { benefits. }\end{array}$ \\
\hline Azom et al. & 2012 & $\begin{array}{l}\text { "Environmental Impact } \\
\text { Assessment of Tanneries: A Case } \\
\text { Study of Hazaribag in Bangladesh" }\end{array}$ & $\begin{array}{l}\text { Physical health of related residential area's people is better than } \\
\text { that of tannery workers. They also found that tannery creates } \\
\text { the job opportunity. }\end{array}$ \\
\hline Rouf & 2013 & $\begin{array}{l}\text { "Characterization of effluents of } \\
\text { leather industries in Hazaribagh } \\
\text { area of Dhaka city" }\end{array}$ & $\begin{array}{l}\text { The odour of the samples was more or less pungent. The colour } \\
\text { of the samples was blackish blue, violet, brown, black etc. }\end{array}$ \\
\hline Khan & 2015 & $\begin{array}{l}\text { "Industry in Bangladesh: } \\
\text { Opportunities and } \\
\text { Challenges" }\end{array}$ & $\begin{array}{l}\text { Leather and leather manufacturers constitute an indispensable } \\
\text { and dependable source for export trade and foreign exchange } \\
\text { earnings. For Bangladesh, leather is a high priority industrial } \\
\text { sector and footwear exports, an extreme focus area. }\end{array}$ \\
\hline
\end{tabular}




\section{CONCLUSION}

Economic impacts are different from the valuation of individual user benefitsof a particular facility or service, and they are also different from broader social impacts. The economic and social impacts may include the valuation of changes in amenity or quality of life factors (such as health, safety, recreation, air or noise quality). Yet while these various types of benefits and impacts may be valued in economic (money) terms, through studies of individuals' or society's "willingness to pay" for improving them, they are not economic impacts except insofar as they also affect an area's level of economic activity.

\section{REFERENCES}

Ahmed AA and Ahmad M. 2009. An Empirical Analysis of Performance Measurement of the Disclosure in Financial Reporting: A Study of Banking Sector in Bangladesh COMSATS Institute if Information Technology 2nd COMSATS International Business Research Conference. Lahore, Pakistan: CIIT.

Ahmed AA and Neogy TK. 2009. Merger \& Acquisitions (M\&A) Goodwill Accounting: Principles and Practice The Bangladesh Accountant, 65, Oct-Dec.

Ahmed AA and Neogy TK. 2010. Forensic Accounting in Bangladesh: Emergence and Introduction Development Compilation, 3, 71-82.

Ahmed AA, Dey MM, Akhter W and Raza A. 2011. Timeliness attributes and the extent of accounting disclosure: a study of banking companies in Bangladesh Interdisciplinary Journal of Contemporary Research in Business, 3, 915-925.

Ahmed AA. 2012. Disclosure of Financial Reporting and Firm Structure as a Determinant: A Study on the Listed Companies of DSE ASA University Review, 6, 44-60.

Ahmed, KA. (1997) "Surface waterpollution from leather industries", Bangladesh Leather 1997 Vol.11, No 17, 9-15, Dhaka.

Ansari, ARK. (2004) "Origin and Prospect of Leather Industry in Bangladesh", souvenir DILF-2004, Dhaka.

Azom, M.R., Mahmud, K., Yahya, S. M., Sontu, A \&Himon, S.B. (2012). Environmental Impact Assessment of Tanneries: A Case Study of Hazaribag in Bangladesh. International Journal of Environmental Science and Development, Vol. 3, No. 2, April 2012.

Chile, L., \& Talukder, D. (2014). The Paradox of Agricultural Trade Liberalization in Bangladesh and Tanzania.American Journal Of Trade And Policy, 1(1), 23-31.

Chowdhury, AH. (1982) Study report on "leather tanning and leather products in Bangladesh", Bangladesh Small and Cottage Industries Corporation, Dhaka.

Chowdhury, M., \& Chowdhury, A. (2015). Problems and Prospects of Potato Cultivation in Bangladesh. Asian Business Review, 5(1), 28-32.

Das, S. (2014). Congruence Properties of Andrews'SPTFunction. ABC Journal Of Advanced Research, 3(2), 47-56.

EPB (1980) "Report of the Committee on Development of Leather Export", Export Promotion Bureau. Dhaka.

Faiz, N. and Islam, R. (1988) "The Leather and Leather Product Industry and The Informal Credit Market in Bangladesh", BIDS working Paper No. 6, November, 1988, Dhaka.

Hossain, M. (2013). Leasing: An Alternative Financing Mechanism for SMEs. ABC Journal Of Advanced Research, 2(1), 66-82.
Huq, MM. and Islam, KMN. (1990) “Choice of Technology in Fertilizer Manufacture in Bangladesh", UPL, Dhaka.

Huq, MM. and Islam, KMN. (1990) "Choice of TechnologyLeather Manufacturing in Bangladesh", pp.17-18, UPL, Dhaka.

Huq, MM. and Islam, KMN. Islam, N. (1993) "Machinery Manufacturing in Bangladesh". UPL, Dhaka.

Huq. MM. and Ahmed KA. (1990) "The Bangladesh Leather Sector- Strategy for Further Development HIID's ESEP Project", Bangladesh Planning Commission, Government of Bangladesh, February, Dhaka.

Islam, K. (2015). Foreign Direct Investment (FDI) in Bangladesh: Prospects and Challenges and Its Impact on Economy. Asian Business Review, 4(1), 24-36.

Islam, M., \& Mondal, T. (2013). Potentiality of Biomass Energy for Electricity Generation in Bangladesh. Asian Journal Of Applied Science And Engineering, 2(2), 103-110.

K.M. Mohapatra and KavitaStivastava (2002), Socio-economic Nexus and Production Relations : The Case of Leather Goods Industry in Kanpur, Economic and Political Weekly.

Karim, MF. (1996) "Export Prospect for Leather and Leather Product", Industrialization strategy study of Bangladesh, Paper No. 12, WB Resident Mission, Dhaka, 31 July.

Khan, W. (2014). Leather Industry in Bangladesh: Opportunities and Challenges. American Journal Of Trade And Policy, 1(3), 117-124.

Krishna and Sahota (1991) "Technical Efficiencies in Bangladesh Manufacturing Industries", The Bangladesh Development Studies, Vol. XIX, 1991

Krishna, K. L., \& Sahota, G. S. (1991).Technical Efficiency in Bangladesh Manufacturing Industries.The Bangladesh Development Studies, 89-105.

Luo, C. (2014). Circular Economy and Urban Waste Resources Recycling. American Journal Of Trade And Policy, 1(2), 71-73.

Manzur, SN. (1994)“Development of Leather Goods For Export: Problems, Prospects \& Policy Support", July 26.

Mekonen, M., Tesfaye, K., \& Bayu, W. (2013). Soil Drainage and Nutrient Management to Improve Productivity of Waterlogged Vertisols for Small-scale Farmers. Engineering International, 1(2), 27-39.

Mohamed, A. (2015). Measuring Productivity Growth of Manufacturing Sector in Thailand. American Journal Of Trade And Policy, 2(2).

Mwase, D. (2015). Performance of Floriculture Industry in East Africa: What Lessons can Tanzania Learn from Kenya?. Asian Business Review, 5(1), 20-27.

Raha, SK. (1993) "Supply Situation of Hides and skins in Bangladesh", Bangladesh Journal of Animal Science, 22(1-2), pp.1-11.

Report of the committee on development of leather export, Export Promotion Bureau, Ministry of Commerce, Government of Bangladesh, March 1980.

Rouf, M. A., Islam, M. S., Haq, M. Z., Ahmed, N., \&Rabeya, T. (2013).Characterization of effluents of leather industries in Hazaribagh area of Dhaka city.Bangladesh Journal of Scientific and Industrial Research, 48(3), 155-166.

Rouf, Md. Abdur and Hasan, Md. Salim and Ahmed, Alim Al Ayub, Financial Reporting Practices in the Textile Manufacturing Sectors of Bangladesh (2014). ABC Journal of Advanced Research, Volume 3, No 2, pp. 57-68, 2014. Available at SSRN: http:/ / ssrn.com/abstract $=2567577$

Souvenir DILF (Dhaka International Leather Fair) 2000, 2001, 2002, 2003, 2004, 2005. 
Stephens, ES. (1977) "The Leather Industry in Bangladesh, Dhaka", International Trade Center, Export Promotion Bureau, Dhaka.

Tesfaye, E. (2014). Determinants of Agricultural Export in SubSaharan Africa: Evidence from Panel Study. American Journal Of Trade And Policy, 1(2), 62-70.

Wijesinghe, J., Wicramasinghe, I., \& Saranandha, K. (2015).
Kithul flour (Caryota urens) as new plant origin Gelatinizing agent with a product development of fruitbased dessert. Engineering International, 2(2), 72-78.

Zahur, M. (2006). Solid waste management of Dhaka city: public private community partnership.

$--0-$ 